HEALTH PSYCHOLOGY REPORT · VOLUME 6(2), 2018 ORIGINAL ARTICLE
Hanna Liberska Aleksandra Grudzińska

$1 \cdot \mathrm{A}, \mathrm{D}, \mathrm{E}, \mathrm{F}$

Monika Deja

$1 \cdot \mathrm{B}, \mathrm{C}, \mathrm{D}, \mathrm{E}$

Joanna Starostecka

$1 \cdot \mathrm{B}, \mathrm{F}, \mathrm{G}$

Martyna fanicka

$1 \cdot \mathrm{B}, \mathrm{D}, \mathrm{E}$
Aleksandra Wolska

$1 \cdot \mathrm{B}, \mathrm{F}$

Katarzyna Dąbek

$2,3 \cdot \mathrm{B}$

\title{
Identity and crisis in evaluation in young fathers in relation to age of the child
}

\section{BACKGROUND}

The fact of becoming a father is related to the necessity of taking up a number of new commitments. The changes following from taking up a new social role generate much stress and can bring some identity transformations (Freudenreich, Liberska, \& Miluska, 2011) and a crisis in evaluation (Trempała, 2010).

\section{PARTICIPANTS AND PROCEDURE}

In order to characterise the structure of identity of young fathers and to determine whether they suffer from a crisis in evaluation, a study was performed on 90 men who became fathers of their first child in the period up to about half a year earlier. Techniques used in the study were: $D i-$ mensions of Identity Development Scale (DIDS), Questionnaire for Investigation of Crisis in Evaluation, and a questionnaire prepared by the author.

\section{RESULTS}

The structure of identity of young fathers has no relation to the age of the child, at least in the first six months of the child's life, but it is related to the crisis in evaluation.

\section{CONCLUSIONS}

According to the results, the crisis in evaluation in young fathers is of intermediate intensity and is related to the age of the child.

The study suggests a relationship between normative events related to the world of the child and a psychological crisis, involving identity and structures of values.

\section{KEY WORDS}

adaptation; reliability; family resilience

ORganization - 1: Institute of Psychology, Casimir the Great University, Bydgoszcz, Poland · 2: Chair and Department of Obstetrics and Pathology of Pregnancy, Medical University of Lublin, Lublin, Poland · 3: Neonatal Unit with Intensive Medical Care, Regional Clinical Hospital No. 1, Rzeszów, Poland

aUthors' Contributions - A: Study design - B: Data collection - C: Statistical analysis - D: Data interpretation .

E: Manuscript preparation · F: Literature search · G: Funds collection

CORRESPONDING AUthor - Prof. Hanna Liberska, Institute of Psychology, Casimir the Great University,

1 Staffa Str., 85-867 Bydgoszcz, Poland, e-mail: hanna.liberska@op.pl 


\section{IDENTITY OF YOUNG FATHERS}

According to the literature, early adulthood is related to certain roles and tasks and social dilemmas (Buist, Morse, \& Durkin, 2002; Gurba, 2011; Liberska \& Malina, 2011; Malina, 2014). One of the conditions of pro-developmental tackling the dilemma of early adulthood concerning intimacy versus social isolation is the preceding formation of a stable identity. A number of contemporary authors indicate the slowing down of the rate of identity development processes and extension of the moratorium phase (Liberska, 2007; Arnett, 2014). These phenomena can be treated as a result of increasing complexity of the life context and a high number of alternative pathways of development offered to young people by contemporary society (Asenhed, Kilsta, Alehage, \& Baggens, 2013).

As a consequence of transformations taking place in western culture societies, manifested as an increasing number of well-educated young people, increased income and consumer spending, the motivation of young people to take up commitments and engage in adult social roles such as motherhood and fatherhood is decreasing (Buhl \& Lanz, 2007; Tremblay \& Pierce, 2011; Planalp \& Braungart-Rieker, 2016). The problem has been recognised in the Arnett (2000) conception of emerging adulthood. According to this author, as a result of continuing socio-cultural and economic transformations and a rapid advance in technology, a new phase of human development appeared, assigned to persons between the age of 18 and 29. Arnett has noted that the phase of emerging adulthood is characterised by: (1) exploration of identity, (2) instability manifested as a frequent change of partners, (3) orientation towards oneself and one's personal development, (4) the sense of being between adolescence and adulthood, (5) high sense of possibilities and high hopes. All these factors mean that young people postpone taking up commitments and identification with them, so also postpone the formation of identity (Arnett, 2000, 2014). Another observed consequence of the above-described phenomena is the extension of the exploration phase.

The shift of the age at which many young adults take up serious commitments means that they take up the social roles associated to this developmental stage later in life (Piotrowski, 2015). This phenomenon can also be observed on the basis of the Central Statistical Office (GUS) in Poland. According to the data of this office for 2015, the mean age of marriage is now 29 years for men and 27 for women. For comparison, in 1990 almost half of men married before 25 years of age. The age at which most marriages are entered into has shifted from 20-24 to 25-29 years of age. The demographic changes that started in Poland in the 1990s also caused a shift in the highest fertility of women from 20-24 to 25-29 years of age (GUS, 2015). The fertility of women aged 30-34 has considerably increased, which is mainly a consequence of postponement of having a child to later years in life. Also the median age at which women have the first child has shifted from nearly 24 years in 2000 to slightly over 27 at present. These changes are accompanied by a drastic change in the level of education of newly married couples. In the 1990 s only $4.00 \%$ of women and $5.00 \%$ of men reported having university level education. In 2013 this proportion had increased to $33.00 \%$ of couples. The changes are a consequence of the choice made by the young generation of Poles, who want to have a certain education and economic stabilisation prior to starting a family (at about 30 years of age).

\section{IDENTITY AND THE CRISIS IN EVALUATION}

According to recent studies, the identity of adolescents is not a stable structure (Luyckx et al., 2007; Päivi, Lea, \& Katja, 2016). Also after the period of adolescence an intense process of identity transformations, related to significant changes in life, takes place. Assuming new social roles and commitments as well as changes that are unavoidable stressful elements of human functioning imply continuous transformations of identity (Bosma \& Kunnen, 2001). Whitbourne and Weinstock (1979) have proposed a conception of the continually changing identity. Thanks to the experience gained in life, people continuously develop and improve their identities. In the light of this conception it can be expected that becoming a father is an event that can change the structure of identity of men (Plopa, 2011). The crisis in identity can be manifested in many developmental phases of people, in particular in the circumstances in which an individual must continually integrate new conditions and demands with the image of him/ herself (Przetacznik-Gierowska, 2011).

As one of the manifestations of the formed sense of identity is development of a system of values as an integral element of identity (Rokeach, 1979; Côté, 1997; Piotrowski, 2015), it can be supposed that the events forcing restructuration of identity, such as becoming a father, will be also related to disintegration of the hierarchy of values.

As expressed by Plopa: "The researchers studying the transition to parenthood from the late 1950s until the present have been writing about the potential stressors of young parents, including the break of hitherto routine habits, tiredness, excess of work, growing financial problems, excessive interference of other family members and others." (after: Plopa, 2011, p. 21). The fact of becoming a father implies assuming many new commitments related to e.g. the responsibility for the child's upbringing and supporting the family. Often this situation requires the need to give
Fathers: identity and crisis 
Hanna Liberska, Monika Deja, Joanna Starostecka, Martyna Janicka, Aleksandra Grudzińska, Aleksandra Wolska, Katarzyna Dąbek up attractive activities, putting off individual ambitions to take care of the child and the family. In such conditions the probability of appearance of the crisis of evaluation increases.

The crisis in evaluation based on the fundamental assumptions of humanistic psychology can be analysed in the following dimensions (Masłowski, 2007):

- Problems with the hierarchy of values when a conflict appears between the main values, which leads to difficulties in defining superior values.

- Re-evaluation that is abandonment of earlier appreciated values and adoption of the newly discovered values.

- The lack of integration of the cognitive and affective - motivating processes, observed when there is no coherence between the values declared and the natural values (predispositions and abilities).

- Problems with evaluation and decision making on the basis of the accepted system of values, manifested when the system of values does not have the regulating function.

- Unrealised values that manifest the conscious divergence between the behaviour of a person and the system of his/her values.

\section{OWN STUDY}

\section{PERSONS TAKING PART IN THE STUDY}

The study was performed with participation of 90 men who became fathers of their first child at about 6 months prior to the study. The age of the participants varied from 21 to $44(M=29.56, S D=3.96)$. The level of education and place of residence of the participants are given in Table 1 .

From the 90 participants, 14 live in informal relations with the child's mother and 76 are in marriages. The mean time from making a decision of living together (including the decision to marry) to child conception varied from 0 (the woman conceived on the first night together) to 192 months, which gives a mean of 25.33 months $(S D=26.84)$. Forty-one of the men $(45.60 \%)$ fathered a son, while 49 of them $(54.40 \%)$ fathered a daughter. The majority of their children (79, which makes $87.80 \%$ ) were born at the expected date and none of them had genetic disorders or diseases. From among the 90 participants, 28 men $(31.50 \%)$ took part in childbirth education classes with their partner, while $55(61.10 \%)$ were present during childbirth. As to the support from the further family, 80 men $(88.90 \%)$ stated that they receive support in childcare, while $10(11.10 \%)$ reported receiving no support.

\section{RESEARCH PROBLEMS AND HYPOTHESES}

The research questions posed are as follows.

1. Do young fathers experience an intensified crisis in evaluation?

2. What is the structure of identity of young fathers?

3. Is the crisis in evaluation experienced by young fathers related to intensification of identity processes?

4. Is the child's age related to the identity development processes and the crisis in evaluation observed in young fathers?

\section{TOOL OF INVESTIGATION}

In order to answer the research questions and verify the hypotheses, the studies were performed in which the Dimensions of Identity Development Scale (DIDS), Questionnaire for Investigation of Crisis in Evaluation and the questionnaire prepared by the author were applied.

\section{DIMENSIONS OF IDENTITY DEVELOPMENT SCALE (DIDS)}

The authors of this questionnaire are K. Luyckx, S. Schwartz, M. D. Berzonsky, B. Soenens, M. Vansteen-

Table 1

Characteristics of participants (level of education and place of living)

\begin{tabular}{|c|c|c|c|c|c|}
\hline \multirow[t]{2}{*}{ Place of living } & \multicolumn{4}{|c|}{ Level of education $N(\%)$} & \multirow{2}{*}{$\begin{array}{l}\text { Total } \\
N(\%)\end{array}$} \\
\hline & Primary & Vocational & Secondary & Higher & \\
\hline Village & $2(2.20 \%)$ & $7(7.80 \%)$ & $18(20.00 \%)$ & $8(8.90 \%)$ & $35(38.90 \%)$ \\
\hline City up to 50 thousand & 0 & $2(2.20 \%)$ & $1(1.10 \%)$ & $3(3.30 \%)$ & $6(6.70 \%)$ \\
\hline City over 100 thousand & 0 & $1(1.10 \%)$ & $5(5.60 \%)$ & $4(4.40 \%)$ & $10(11.10 \%)$ \\
\hline City up to 250 thousand & $1(1.10 \%)$ & 0 & $3(3.30 \%)$ & $9(10.00 \%)$ & $13(14.40 \%)$ \\
\hline City over 250 thousand & 0 & $3(3.30 \%)$ & $2(2.20 \%)$ & $21(23.30 \%)$ & $26(28.90 \%)$ \\
\hline Total N (\%) & $3(3.30 \%)$ & $13(14.40 \%)$ & $29(32.20 \%)$ & $45(50.00 \%)$ & $90(100.00 \%)$ \\
\hline
\end{tabular}


kiste, I. Smits, and L. Goossens. It has been adapted to Polish conditions by I. Brzezińska and K. Piotrowski (Brzezińska, Piotrowski, 2010). This tool permits identification of the position of an individual in the five dimensions proposed by Koen Luyckx et al. (Luyckx et al., 2008; Brzezińska, Piotrowski, 2009, 2010), that is in the dimensions exploration in breadth (EB), exploration in depth (ED), ruminative exploration (ER), commitment making (PZ) and identification with commitment (IZ).

A detailed theoretical description is given by Brzezińska and Piotrowski (2009). The exploration in breadth scale describes the range in which the individual looks for alternative aims, convictions and values prior to making commitments. Additionally, the same scale describes the degree to which an individual muses upon his/her future and tries to find which style of living will be most suitable for him/her.

Exploration in depth refers to the deepened evaluation of decisions and choices made to check to what degree the commitments made are in conformity with personal standards; it describes the degree to which the individual considers the commitments made and talks about them with other persons to learn their opinion.

The ruminative exploration scale describes the level of anxiety of the individual and problems in engagement in the areas important for development of identity. High results on this scale indicate problems with obtaining satisfactory answers to questions related to identity, which can lead to experiencing lack of self-confidence or the sense of incompetence and further on to increase in the level of tension.

The scale of commitment making informs about the range of choices and commitments made that are important for individual identity development. The information elicited on the basis of responses to the questions from this scale permits estimating the degree to which the individual believes that he/ she made the right decision on the direction to follow and is aware of what he/she wants to achieve in future.

The scale of identification with commitment provides the information on the degree of the individual identification with the commitments and choices made. It also estimates the degree of their internalization and degree of conviction that the choices made were right. In other words, the responses to the questions representing this scale inform about the degree to which the individual believes that the commitments made give him/her a sense of security and self-confidence and the sense that his/her future plans are in conformity with his/her expectations and lifestyle.

The responses of the person taking part in the study are scored on the scale from 1 to 6 . The responses belonging to each scale are scored separately so that five results representing responses to five scales are obtained. The result is the mean score on a given scale, so the minimum score is 1 and the maximum 6 .

The scales measure five separate, although interrelated, factors, and no general result is calculated.

\section{QUESTIONNAIRE FOR INVESTIGATION OF THE CRISIS IN EVALUATION}

The variable 'crisis in evaluation' was measured on the basis of the Questionnaire for Investigation of the Crisis in Evaluation (KKW) proposed by P. Oleś (1989). The questionnaire provides information on the difficulties in evaluation. The questions refer to different aspects of evaluation, which are manifested by the character of aims chosen and striving towards their achievement. The questionnaire comprises 25 claims; the first is not diagnostic and acts a buffer. The respondent is asked to consider each claim and choose one of the 3 possible answers: true $(P)$, I am not sure (?) or False (F). Each diagnostic response is scored with 2 so the range of raw results varies from 0 to 48 . The tool comprises 4 subscales referring to different symptoms of the crisis in evaluation.

a) Scale $H$ (problems with hierarchy) - a high score on this scale indicates many doubts concerning life values, problems with choosing the superior value and problems with hierarchizing of the values. It can be an outcome of a conflict or insufficient reflections over values. Moreover, it can indicate the search for values.

b) Scale $Z$ (sense of losing values) - a high score on this scale is related to the sense of being lost, losing values, sense of the lack of important values, life patterns and ideals that one would like to strive for. A high score also suggests the sense of loss of the meaning of values and their justification, which is related to disappointment or conviction of the unsuitable choice of life aims. The results on this scale also inform about changes in the system of values.

c) Scale $D$ (disintegration of evaluation) - a high score on this scale implies low motivation for achievement of aims and values, low perseverance and reduced emotional acceptance of values. A high score can suggest a divergence between the values and motivation for their achievement and a lack of satisfaction from their achievement. It is also possible that the respondent has a negative evaluation of his behaviour and treats it as unrelated to his/her own system of values.

d) Scale $R$ (sense of the lack of achievement of values) - a high score indicates intensified sense of the lack of achievement of accepted values, the sense that one's behaviour is inconsistent with the accepted system of values and that values have too weak regulation potential.
Fathers: identity and crisis 
The total score in KKW is a measure of the level of difficulties in the process of evaluation. The coefficient of internal consistency for the whole scale was Cronbach's $\alpha=.90$, and the reliability of subscales varied in the range .73 to .76 . These values are high enough to treat the questionnaire as a rather accurate tool for diagnosis of problems and disturbances in evaluation (Oleś, 1989).

Hanna Liberska, Monika Deja, Joanna Starostecka, Martyna Janicka, Aleksandra Grudzińska, Aleksandra Wolska, Katarzyna Dąbek

The participants were also asked to fill in a special form

\section{A FORM} to collect the information on their age, place of living, level of education, sex and age of the child, participation in childbirth classes, presence at the childbirth and support from the family in taking care of the child.

\section{RESULTS}

\section{INCREASED INTENSITY OF THE CRISIS IN EVALUATION}

The crisis in evaluation observed in the group of young fathers can be described as of intermediate intensity, Table 2.

Only the range of the crisis in the dimension of the sense of the loss in the world of values is at an elevated level.

\section{CRISIS IN EVALUATION AND THE CHILD'S AGE}

The significance of differences in the intensity of the crisis of evaluation in particular dimensions, between the groups of men studied, is presented in Table 3.

The significance of differences between the mean results was determined by the post hoc Tukey test for unequal $N$. The mean values labelled with the same letters in the lines differ significantly from one another at least at the level of $p=.050$.

According to our results, in the group of young fathers studied the intensity of the crisis in evaluation depends on the age of their first child. The lowest intensity of the crisis is manifested in the first month of the child's life. In the subsequent months the crisis was observed in disintegration of values, divergence between the earlier accepted values and presently accepted ones (Scale D, $F(2,89)=4.78, p=.011$ ) and in the sense of the lack of achievement of the earlier accepted values (Scale $R, F(2,89)=3.18, p=.047)$.

\section{STRUCTURE OF YOUNG FATHERS' IDENTITY}

Table 4 presents the mean intensity of identity development processes in particular dimensions measured by the Dimensions of Identity Development Scale (DIDS). In the group of young fathers studied, the highest results were noted in the dimensions of identification with commitment and commitment making.

Table 2

Increased intensity of the crisis in the group of young fathers

\begin{tabular}{lcccc}
\hline KKW & $M$ & $S D$ & Sten & Result \\
\hline KKW sum & 8.63 & 10.64 & 5 & intermediate \\
Scale $D$ & 1.93 & 3.01 & 5 & intermediate \\
Scale $H$ & 3.11 & 3.66 & 5 & intermediate \\
Scale $R$ & 1.87 & 2.44 & $4 / 5$ & reduced/intermediate \\
Scale $Z$ & 1.71 & 3.15 & $6 / 7$ & intermediate/elevated \\
\hline
\end{tabular}

Table 3

Significance of differences in intensity of the crisis of evaluation in particular dimensions

\begin{tabular}{|c|c|c|c|c|c|c|c|c|}
\hline \multirow[t]{2}{*}{ KKW } & \multicolumn{2}{|c|}{$\begin{array}{l}\text { Children aged } \\
\text { up to } 1 \text { month }\end{array}$} & \multicolumn{2}{|c|}{$\begin{array}{c}\text { Children aged } \\
1-3 \text { months }\end{array}$} & \multicolumn{2}{|c|}{$\begin{array}{l}\text { Children aged } \\
4-6 \text { months }\end{array}$} & \multirow[t]{2}{*}{$F(2,89)$} & \multirow[t]{2}{*}{$p$} \\
\hline & $M$ & $S D$ & $M$ & $S D$ & $M$ & $S D$ & & \\
\hline Scale D & 0.98a.b & 1.93 & $3.23 a$ & 3.42 & $2.71 \mathrm{~b}$ & 3.67 & 4.78 & .011 \\
\hline Scale H & 2.28 & 3.07 & 3.85 & 4.28 & 3.97 & 3.98 & 2.29 & .107 \\
\hline Scale $R$ & 1.26a.b & 2.04 & $2.92 a$ & 2.66 & $2.29 b$ & 2.70 & 3.18 & .047 \\
\hline Scale Z & 1.42 & 2.86 & 1.85 & 3.41 & 2.06 & 3.48 & 0.39 & .681 \\
\hline KKW sum & 5.93 & 8.51 & 11.85 & 11.39 & 11.03 & 12.26 & 2.89 & .061 \\
\hline
\end{tabular}




\section{STRUCTURE OF YOUNG FATHERS' IDENTITY AND THE CHILD'S AGE}

Statistical analysis did not reveal significant differences in the dimensions describing identity development depending on the age of the first child of the respondents (Table 5).

\section{THE CRISIS IN EVALUATION AND INTENSITY OF IDENTITY DEVELOPMENT PROCESSES OF FATHERS WITH RESPECT TO THE AGE OF THE FIRST CHILD}

The results collected in Table 6 indicate that the fathers of children aged up to 1 month reveal a significant correlation between the intensity of rumination and disintegration of evaluation (Scale D, $r=.33$, $p=.050)$, the sense of loss in the world of values (Scale $Z, r=.55, p=.050$ ) and problems with their hierarchizing (Scale H, $r=.38, p=.050$ ). Ruminative exploration is also positively correlated with the intensity of crisis in young fathers $(r=.47, p=.010)$. The identity development process of exploration in breadth is also positively correlated with the sense of loss in the world of values (Scale $Z, r=.45, p=.010$ ). The exploration in depth, which is another identity development process, is positively correlated with
Table 4

Structure of young father's identity

\begin{tabular}{lcc}
\hline Identity dimensions (DIDS) & $M$ & $S D$ \\
\hline Exploration in breadth & 3.59 & 0.87 \\
Exploration in depth & 3.57 & 0.75 \\
Ruminative exploration & 2.78 & 0.84 \\
Commitment making & 4.49 & 0.77 \\
Identification with commitment & 4.52 & 0.67 \\
\hline
\end{tabular}

the sense of loss in the world of values (Scale $Z$, $r=.48, p=.010)$, and with the intensity of the crisis in evaluation $(r=.35, p=.050)$. In the fathers of children in the first month of life a significant negative correlation was found between the identification with commitment and the crisis in evaluation $(r=-.42$, $p=.010)$.

The fathers of children at the age of 1 to 3 months show fewer correlations between the dimensions of identity development and particular dimensions of the crisis in evaluation (Table 7). For these fathers the problems with hierarchizing values (Scale $H$ ) were significantly positively correlated with ruminative exploration $(r=.70, p=.010)$ and negatively correlated with commitment making $(\mathrm{r}=-.67, p=.050)$ and identification with commitments $(r=-.74, p=.050)$.

Table 5

Structure of young father's identity and child's age

\begin{tabular}{|c|c|c|c|c|c|c|c|c|}
\hline \multirow[t]{2}{*}{$\begin{array}{l}\text { Identity dimensions } \\
\text { (DIDS) }\end{array}$} & \multicolumn{2}{|c|}{$\begin{array}{l}\text { Children aged } \\
\text { up to } 1 \text { month }\end{array}$} & \multicolumn{2}{|c|}{$\begin{array}{l}\text { Children aged } \\
1-3 \text { months }\end{array}$} & \multicolumn{2}{|c|}{$\begin{array}{l}\text { Children aged } \\
4-6 \text { months }\end{array}$} & \multirow[t]{2}{*}{$F(2,89)$} & \multirow[t]{2}{*}{$p$} \\
\hline & $M$ & $S D$ & $M$ & $S D$ & $M$ & $S D$ & & \\
\hline Exploration in breadth & 3.54 & 0.82 & 3.54 & 0.99 & 3.67 & 0.90 & 0.23 & .793 \\
\hline Exploration in depth & 3.56 & 0.71 & 3.77 & 0.76 & 3.49 & 0.80 & 0.68 & .509 \\
\hline Ruminative exploration & 2.76 & 0.79 & 2.67 & 0.90 & 2.86 & 0.89 & 0.29 & .750 \\
\hline Commitment making & 4.58 & 0.73 & 4.61 & 0.84 & 4.33 & 0.80 & 1.17 & .314 \\
\hline $\begin{array}{l}\text { Identification with } \\
\text { commitment }\end{array}$ & 4.60 & 0.64 & 4.51 & 0.75 & 4.42 & 0.69 & 0.64 & .531 \\
\hline
\end{tabular}

Table 6

Correlation between DIDS and KKW in the group of fathers of children aged up to 1 month

\begin{tabular}{|c|c|c|c|c|c|}
\hline \multirow[t]{2}{*}{ Identity dimensions (DIDS) } & \multicolumn{5}{|c|}{ KKW } \\
\hline & Scale D & Scale $H$ & Scale $R$ & Scale Z & KKW sum \\
\hline Exploration in breadth & & & & $.45^{* *}$ & \\
\hline Exploration in depth & & & & $.48^{* *}$ & $.35^{*}$ \\
\hline Ruminative exploration & $.33^{*}$ & $.38^{*}$ & & $.55^{*}$ & $.47^{* *}$ \\
\hline \multicolumn{6}{|l|}{ Commitment making } \\
\hline Identification with commitment & & & & & $-.42^{* *}$ \\
\hline
\end{tabular}


Table 7

Correlation between DIDS and KKW in the group of fathers of children aged 1-3 months

\begin{tabular}{|c|c|c|c|c|c|}
\hline \multirow[t]{2}{*}{ Identity dimensions (DIDS) } & \multicolumn{5}{|c|}{ KKW } \\
\hline & Scale D & Scale $H$ & Scale $R$ & Scale Z & KKW sum \\
\hline \multicolumn{6}{|l|}{ Exploration in breadth } \\
\hline \multicolumn{6}{|l|}{ Exploration in depth } \\
\hline Ruminative exploration & & $.70^{* *}$ & & & \\
\hline Commitment making & & $-.67^{*}$ & & & \\
\hline $\begin{array}{l}\text { Identification with } \\
\text { commitment }\end{array}$ & & $-.74^{* *}$ & & & $-.59^{*}$ \\
\hline
\end{tabular}

Hanna Liberska,

Monika Deja, Joanna

Starostecka,

Martyna Janicka,

Aleksandra

Grudzińska,

Aleksandra

Wolska,

Katarzyna Dąbek

The dimension of identification with commitments is also correlated with intensity of the crisis in evaluation $(r=-.59, p=.050)$.

The data for the fathers of children aged from 1 to 3 months also reveal a significant correlation between ruminative exploration and the sense of loss in the world of values (Scale $Z, r=.38, p=.050$ ) (Table 8).

\section{DISCUSSION}

One of the aims of the study was to determine whether the age of the first child is related to the identity development processes and crisis in evaluation, in young fathers. To obtain this information, 90 men who became fathers of their first child in the period up to 6 months prior to the study were asked to participate in the investigation.

The first research question was whether the young fathers of their first child up to 6 months old reveal a crisis in evaluation. The results showed that the intensity of the crisis is intermediate. Only the sense of loss in the world of values and abandonment of some hitherto accepted values was at a slightly higher level. On the basis of this result it is expected that the birth of the first child (becoming a father for the first time) provokes in young fathers a need to build a new hierarchy of values as the one they had earlier is no longer adequate. The young fathers go through the loss of the hitherto appreciated values that are replaced by new ones related to fatherhood. This change in the hierarchy of values prompts further changes: some values lose their importance while others gain more of it.

The results collected in the study also revealed that the age of the first child is correlated with the intensity of the crisis in evaluation in the young fathers. On the basis of the Social Readjustment Rating Scale; SRRS, Holmes, Rahe, 1967; Przetacznik-Gierowska, 2011) it was assumed that the fact of childbirth would be a strongly crisis-producing event which would be solved with time. The results obtained indicated a different situation: the crisis in evaluation appears only after the first month of the child's life. The crisis is particularly manifested in the sense of disintegration and not achievement of values, the lack of satisfaction from the hitherto pursued values or in the divergence between the earlier pursued values and the currently accepted ones (see: Bronte-Tinkew, Moore, Matthews, \& Carrano, 2007). In this context becoming a father for the first time is a situation disturbing the system of values, enhancing the sense

Table 8

Correlation between DIDS and KKW in the group of fathers of children aged 4-6 months

\begin{tabular}{|c|c|c|c|c|c|}
\hline \multirow[t]{2}{*}{ Identity dimensions (DIDS) } & \multicolumn{5}{|c|}{ KKW } \\
\hline & Scale D & Scale $H$ & Scale $R$ & Scale Z & KKW sum \\
\hline \multicolumn{6}{|l|}{ Exploration in breadth } \\
\hline \multicolumn{6}{|l|}{ Exploration in depth } \\
\hline Ruminative exploration & & & & $.38^{*}$ & \\
\hline \multicolumn{6}{|l|}{ Commitment making } \\
\hline $\begin{array}{l}\text { Identification with } \\
\text { commitment }\end{array}$ & & & & & \\
\hline
\end{tabular}


of inadequacy of the earlier system and the need for restructuring it anew, taking into account the new value which is the child.

The structure of identity of young fathers is not correlated with the age of the child, at least in the first six months of its life; however, it is correlated with the crisis in evaluation.

In the first month of the children's life, the results collected in our study for their fathers revealed a correlation between the sense of loss in the world of values and the intensity of three dimensions of identity development: exploration in breadth, exploration in depth and ruminative exploration. All these correlations are positive and are moderately strong. The results evidenced that the greater the sense of loss in the world of values, the more intense is the search for new values, verification of the new values and work on the earlier appreciated values, which can lead to new values. The fact that the sense of loss in the world of values is a difficult experience for the young fathers is confirmed by the accompanying increase in the intensity of rumination, which points to the lack of confidence in the current life situation. As mentioned above, the fact of becoming a father for the first time is for men a highly stressful situation as it is related to taking responsibility for the child's upbringing and for providing financial support for the family. Facing this new challenge the young father experiences a crisis in evaluation leading to increased intensity of identity development processes in certain dimensions.

Ruminative exploration is also correlated with disintegration of values and problems with construction of a new hierarchy of values or reproduction of the earlier one. Therefore, it can be supposed that increased intensity of ruminative processes becomes men's response to the experienced disturbances in the system of values. A similar supposition can be made considering the other two types of exploration. Taking into regard the age group of the men studied it can be expected that they have relatively stable structure of identity (Erikson, 1968; Musiał, 2007). On the other hand, taking any type of exploration means that becoming a father, understood as undertaking a new social role, can initiate a crisis in identity related with this fact. However, it cannot be rejected that the childbirth and fatherhood are perceived by men as a harbinger or the cause of other necessary changes in life that must be made, e.g. changes in the relation with the child's mother or with friends or in professional life (see: NICHD Early Child Care Research Network, Rockville, 2000). Thus, the crisis related to changes in one sphere of life can be extended to others, which can lead to superposition of many crises or onset of a sequence of crises. It would explain the observed increased intensity in the crisis in evaluation in the young fathers.

The perception of problems related to fatherhood does not diminish with the child's age but, on the contrary, increases, which makes it difficult for men to make commitments and identify with them.

When the child grows out of the infant stage, strong correlations were noted between the problems with hierarchizing values and the three dimensions of identity development processes: ruminative exploration, identification with commitments and making commitments. It may mean that fathering a 2-3-month-old child is a difficult challenge from the viewpoint of formation of a hierarchy of values. The consequence of this challenge is the impossibility of identification with the challenges of the current life situation and making new commitments concerning the role of a father, husband and other men's roles in society. A comparison of the strength of correlation between the increased intensity of identity development processes in the dimension of ruminative exploration and the intensity of problems with hierarchizing of values determined at different times reveals the increase in the strength in time. The greater the problems with building a new hierarchy of values, the greater are the anxiety and fears of the young father. Thus, it seems that this period is particularly difficult for men. It is supposed that only after formation of a new hierarchy of values or after reconstruction of the earlier one would the young fathers be able to solve the crisis in evaluation and full assumption of the role of a father (see Tremblay $\&$ Pierce, 2011). It requires identification with certain expectations of the father and their achievement.

When a child is older than 3 months, the crisis of young fathers is manifested as a deep sense of loss in the world of values, correlated with ruminative processes. The experience of leaving some of the hitherto approved values to make room for new ones generates instability and lack of confidence. The necessity of building a new hierarchy of values including the new values of a child and family is a source of dilemmas, anxiety and nagging doubts whether one is able to manage the new situation. This observation confirms the long time of the crisis following from becoming a father. A particular manifestation of the crisis is the relation between the disturbed hierarchy of values and ruminative exploration.

\section{CONCLUSIONS}

The hitherto performed analyses have been focused on the necessity of rearrangement of the hierarchy of values in order to include the new values related to the child and family. However, as mentioned above, the problems with undertaking the role of a father can be related to experiences in other spheres, e.g. in relations with the child's mother, different type of child's mother functioning as she is concentrated on the child and not on the man as it had been before the child's birth, and changes in the social position of the
Fathers: identity and crisis 
Hanna Liberska, Monika Deja, Joanna Starostecka, Martyna Janicka, Aleksandra Grudzińska, Aleksandra Wolska, Katarzyna Dąbek man who is also a father. In our culture fathers are expected to meet specific demands not only directly related to the child. Young fathers may have problems with changes in social position in the workplace, changes in social contacts, in spending free time, in relations with other family members, etc. (Liberska, 2001; Plopa, 2011). A man who becomes a father faces the challenge of redefining the conception of himself which now must include fatherhood (Carlson, Kendall, Edleson, \& Jeffrey, 2016). It should be emphasised that a man begins to achieve the social status of his role and his responsibility for bringing up and preparation for the life of a new person: his partner's and his child. This achievement imposes the need for restructuration of the hitherto life plan and conceptualization of fatherhood across life (Kings, Knight, Rayan, \& Macdonald, 2016).

In summary, the results suggest a relationship between normative events related to the world of the child and a psychological crisis, involving identity and structures of values, and provide an empirical confirmation of the role of crises in human development.

\section{REFERENCES}

Arnett, J. J. (2000). Emerging Adulthood. A Theory of Development From the Late Teens Through the Twenties. American Psychological Association, 55, 469-480.

Arnett, J. J. (2014). Emerging Adulthood: The Winding Road from the Late Teens Through the Twenties (2nd ed.). Oksford: Oxford University Press.

Asenhed, L., Kilstam, J., Alehagen, S., \& Baggens, C. (2014). Becoming a father is an emotional roller coaster - an analysis of first-time fathers' blogs. Journal of Clinical Nursing, 23, 1309-1317.

Bosma, H. A., \& Kunnen, E. S. (2001). Determinants and mechanisms in ego identity development: A review and synthesis. Developmental Review, 21, 39-66.

Bronte-Tinkew, J., Moore, K. A., Matthews, G., \& Carrano, J. (2007). Symptoms of major depression in a sample of fathers of infants: Sociodemographic correlates and links to father involvement. Journal of Family Issues, 28, 61-99.

Brzezińska, A. I., \& Piotrowski, K. (2009). Diagnoza statusów tożsamości w okresie adolescencji, wyłaniającej się dorosłości i wczesnej dorosłości za pomocą Skali Wymiarów Rozwoju Tożsamości (DIDS) [A diagnosis of identity status in adolescence, emerging adulthood and early adulthood using the Dimensions of Identity Development Scale (DIDS)]. Studia Psychologiczne, 47, 93-109.

Brzezińska, A. I., \& Piotrowski, K. (2010). Polska adaptacja Skali Wymiarów Rozwoju Tożsamości (DIDS) [Polish adaptation of Dimensions of Identity Development Scale (DIDS)]. Polskie Forum Psychologiczne, 15, 66-48
Buhl, H. M., \& Lanz, M. (2007). Emerging adulthood in Europe: common triats and variability across five European countries. Journal of Adolescent Research, 22, 439-443.

Buist, A., Morse, C., \& Durkin, S. (2002). Men's Adjustment to Fatherhood: Implications for Obstetric Health Care. Clinical Research, 22, 172-180.

Carlson, J., Kendall, A., \& Edleson, J. L. (2015). Becoming a Good Father: The Developmental Engine of First-Time Fatherhood. Fathering: A Journal of Theory, Research, and Practice about Men as Fathers, 3, 182-202.

Côté, J. E. (1997). An empirical test of the identity capital model. Journal of Adolescence, 20, 577-597.

Erikson, E. (1968). Identity - Youth and crisis. New York: W. W. Norton.

Freudenreich, D., Liberska, H., \& Miluska, J. (2011). Man's engagement in family life - changes and contexts. In H. Liberska (Ed.), Relations in marriage and family: genesis, quality and development (pp. 153-174). Bydgoszcz: Wydawnictwo Uniwersytetu Kazimierza Wielkiego.

Gurba, E. (2011). Wczesna dorosłość [Early adulthood]. In J. Trempała (Ed.), Psychologia rozwoju człowieka [Psychology of human development]. Warszawa: Wydawnictwo Naukowe PWN.

GUS. (2015). Projekt EUROSTATu dotyczacego dzietności, zawierania i rozpadu matżeństw oraz stanu cywilnego ludności w poszczególnych krajach Unii Europejskiej [The Eurostat project on fertility, the conclusion and dissolution of marriages and civil status of the population in the countries of the European Union]. Retrieved from http://stat.gov.pl/obszarytematyczne/ludnosc/ludnosc/malzenstwa-i-dzietnosc-w-polsce,23,1.html [Accessed: 2016 May 24].

Holmes, T. H., \& Rahe, R. H. (1967). The Social Readjustment Rating Scale. Journal of Psychosomatic Research, 11, 213-218.

Kings, C. A., Knight, T., Rayan, D. R., \& Macdonald, J. A. (2016). The 'Sensory Deprivation Tank': An Interpretative Phenomenological Analysis of Men's Expectations of First-Time Fatherhood. Psychology of Men \& Masculinity, 18, 112-122.

Liberska, H. (2001). Oczekiwania dotyczące własnej osoby i przyszłego partnera małżeńskiego w przededniu dorosłości [Expectations about one's own a person and a future marital partner on the eve of adulthood]. In H. Liberska \& M. Matuszewska (Eds.), Matżeństwo: męskość-kobiecość, mitość, konflikt [Marriage: masculinity-femininity, love, conflict]. Poznań: Wydawnictwo Fundacji Humaniora.

Liberska H. (2007). Współczesny obraz moratorium [The modern picture of the moratorium]. In $\mathrm{H}$. Liberska \& B. Harwas-Napierała (Eds.), Tożsamość a wspótczesność. Nowe tendencje i zagrożenia [Identity and modern times. New tendencies and threats] (pp. 25-52). Poznań: Wydawnictwo Naukowe UAM. 
Liberska H., \& Malina A. (2011). Developmental tasks of early adulthood in the light of psychology human development. In H. Liberska (Ed.), Current psychosocial problems in traditional and novel approaches (pp. 39-57). Bydgoszcz: Wydawnictwo Uniwersytetu Kazimierza Wielkiego.

Luyckx,K.,Soenens, B.,Vansteenkiste, M., Goossens, L., \& Berzonsky, M. (2007). Parental psychological control and dimensions of identity formation in emerging adulthood. Journal of Family Psychology, 21, 546-550. doi: http://dx.doi.org/10.1037/08933200.21.3.546

Luyckx, K., Schwartz, S. J., Berzonsky, M. D., Soenens, B., Vansteenkiste, M., Smits, I., \& Goossens, L. (2008). Capturing ruminative exploration: Extending the four-dimensional model of identity formation in late adolescence. Journal of Research in Personality, 42, 58-82.

Malina, A. (2014). Wczesna dorostość w cyklu życia człowieka: wspótczesne problemy z realizacją zadań rozwojowych mtodych dorostych [Early adulthood in the life cycle of human: contemporary problems with the implementation of developmental tasks by young adults]. Bydgoszcz: Wydawnictwo UKW.

Masłowski, A. (2007). Osobowościowe korelaty kryzysu w wartościowaniu [Personality and the crisis of evaluation]. In P. Francuz \& W. Otrębski (Eds.), Studia z Psychologii w KUL [Lectures in psychology at the Catholic University of Lublin] (pp. 5771). Lublin: Wydawnictwo KUL.

Musiał, D. (2007). Kształtowanie się tożsamości w adolescencji [Development of identity in adolescence]. In P. Francuz \& W. Otrębski (Eds.), Studia z Psychologii w KUL [Lectures in psychology at the Catholic University of Lublin]. (pp. 73-92). Lublin: Wydawnictwo KUL.

NICHD Early Child Care Research Network Rockville, Maryland. (2000). Factors Associated With Fathers' Caregiving Activities and Sensitivity With Young Children. Journal of Family Psychology, 2, 200-219.

Oleś, P. (1989). Kwestionariusz do Badania Kryzysu w Wartościowaniu. Podręcznik [Value Crisis Questionnaire (VCQ). Mannual]. Warszawa: Polskie Towarzystwo Psychologiczne.

Päivi, F., Lea, P., \& Katja, K. (2016). Identity Formation in Adulthood: A Longitudinal Study from Age 27 to 50. Identity. An International Journal of Theory and Research, 16, 8-23. doi: http://dx.doi.org/ 10.1080/15283488.2015.1121820

Planalp, E. M., \& Braungart-Rieker, J. M. (2016). Determinants of Father Involvement With Young Children: Evidence From the Early Childhood Longitudinal Study-Birth Cohort. Journal of Family Psychology, 1, 135-146.

Piotrowski, K. (2015). Kapitał tożsamości uczniów szkół ponadgimnazjalnych [The identity capital of post-middle school students]. Studia Psychologiczne, 53, 47-61.

Plopa M. (2011). Rodzicielstwo jako wyzwanie dla małżeństwa: perspektywa teorii systemowej [Parenting as a challenge for marriages: the prospect of systemic theory]. In H. Liberska \& A. Malina (Eds.), Wybrane problemy wspótczesnych matżeństw i rodzin [Selected problems contemporary marriages and families]. Warszawa: Difin.

Przetacznik-Gierowska M. (2011). Zasady i prawidłowości psychicznego rozwoju człowieka [Rules and regularities of mental human development]. In M. Przetacznik-Gierowska \& M. Tyszkowa (Eds.), Psychologia rozwoju człowieka [Psychology of human dvelopment] (pp. 57-84). Warszawa: Wydawnictwo Naukowe PWN.

Rokeach, F. (1979). Understanding human values. New York: The free press.

Tremblay, S., \& Pierce, T. (2011). Perceptions of fatherhood: Longitudinal reciprocal associations within the couple. Canadian Journal of Behavioural Science, 2, 99-110.

Trempała J. (2010). Obsesyjna miłość rodziców do dziecka: Przyczynek do dyskusji [Excessive parental love. A contribution to the actual discussion]. Roczniki Naukowe. Seria A, Nauki spoteczne, 1-2, 169-179.

Whitbourne, S. K., \& Weinstock, C. S. (1979). Adult Development: The Differentiation of Experience. New York: Holt, Rinehart and Winston.
Fathers: identity and crisis 